\title{
Unholy Development: Religion as an Emerging Voice in the Global Debate on the Future of the Planet ${ }^{2}$
}

Today's world is facing socio-environmental challenges that require more than technical, legal and political responses. There is a need for broader ethical and existential responses and, above all, a need for a dialogue between these different dispersed and inarticulate responses. Techno-scientific explanations are usually mobilized to explain the current environmental situation, diagnose the crisis and make prescriptions for an urgent change, leaving out a potentially important activator: religion. Historically, however, religion has significantly influenced the ways of feeling, thinking and acting, considering the main aspects of individual and collective life, including the relationship between humans and non-human nature. Consequently, thinking about the role of religion for a socio-ecological transition can contribute to an expanded understanding of sustainability ${ }^{3}$ (which includes

\footnotetext{
1 ADRIAN BELING is an Associate Researcher in the Global Studies Programme at the Latin American Social Sciences Institute (FLACSO) in Argentina. JULIEN VANHULST is professor at the Universidad Catolica del Maule, in Chile.

2 This article was originally published in http://www.alternautas.net/blog/2019/10/4/7tvl5pecgz8avq6qtalp72q1cgum52 on October $4^{\text {th }}$, 2019. This article is based on the introduction to the book "Desarrollo Non Sancto. La religión como actor emergente en el debate global sobre el futuro del planeta", edited by Adrián Beling and Julien Vanhulst and published by Siglo XXI.

3 In the last 30 years, the idea of "sustainable development" has catalyzed the debate around the sustainability imperative (Vanhulst, 2015; Vanhulst \& Beling, 2013; Vanhulst \& Zaccai, 2016). However, this notion is controversial because it has served to express a wide range of responses **
} 
economic, ecological, social and spiritual well-being) and its cultural inception, as well as its possible influence on daily policies, programs and practices to ensure the construction of societies capable of future.

There are already studies have analyzed the role of religion in the transition to socioecological sustainability (i.a. Gottlieb, 2006a, 2006b; Jenkins, Tucker, \& Grim, 2016; Tucker, 2008, 2015) and shown that religious thought can contribute to a global cultural dialogue about the relationship between humanity and its natural environment. Among these authors, some consider religion as a "cultural resource" (Hulme, 2016; Perkiss \& Tweedie, 2017) that allows to build normative, practical and institutional answers to the challenges of the environmental crisis. Indeed, religion allows, on the one hand, to build narratives (through beliefs, traditions, and ethical principles) to think and legitimize desirable forms of life in harmony with others and with the environment. On the other hand, we observe that religions promote individual and collective practices and behaviors pro (or anti-) socioecological sustainability. Finally, as an institutional actor, religion intervenes in politic debate and in programmatic action, transferring legitimacy, building alliances, setting agenda, influencing the direction of social debate, as well as designing, financing and executing infrastructure and intervention programs in the socioeconomic fabric of communities throughout the world. Thus, religion has ever accompanied the historical evolution of humanity, on these three levels: cultural imaginary, social and institutional praxis.

In this article, we propose a reflection on the current and potential role of religion in the necessary "Great Socio-Ecological Transformation" of our modern world, a transformation of scope and depth analogous to that described by economic anthropologist Karl Polanyi in the mid-twentieth century. Polanyi's work has

to the socio-environmental debate, from conservative visions to proposals for radical transformation (Lélé, 1991, 2013; Sneddon, Howarth, \& Norgaard, 2006; Van Opstal \& Hugé, 2013; Villalba, 2009). Here we prefer to use the word "sustainability" and "socio-ecological sustainability" to describe a new social configuration that abandons what has been called the "paradigm of the most exceptional human" and approaches a "new ecological paradigm" (Catton \& Dunlap, 1978, 1980; Dunlap \& Catton, 1979); that is to say a social configuration based on the awareness of (a) the social interdependence of all humanity, (b) the interdependence between humanity and nature and (c) the finitude of planet Earth. 
enjoyed a certain revival in recent years (Somers and Block, 2014), while his opus magnum, The Great Transformation (Polanyi, 1944), is widely regarded as the most eloquent, analytical and metaphorical account of the scale and scope of the changes that modern societies will face in the twenty-first century. In addition, Polanyi's work emphasizes an aspect of modern capitalism that has been overshadowed in contemporary thought: namely, capitalism as a relatively new accumulation system in historical terms, which was introduced through a "Great Tranformation" in the England of the eighteenth and nineteenth centuries, through a systematic effort to "shape human nature for industrial growth" (Paulson, 2017, p. 440). However, contrary to the undeliberated and unplanned "great transformations" of the past (such as the Neolithic and industrial revolutions), the uniqueness of the necessary transformation towards an ecologically viable society is to promote a comprehensive restructuring of the world based on an anticipatory and precautionary logic. Indeed, the long "stopping distance" - that is, the long lag between the moment of generation of causes and the moment of the visible manifestation of the effects that characterize many global environmental problems (for example, climate change or biodiversity loss)_requires overcoming traditional ex-post reactions in response to clearly perceived crises or disasters. To be successful, the "Great Socio-Ecological Transformation" must be anticipated (wbgu, 2011: 5).

We start the the present reflection with the encyclical letter of Pope Francis, Laudato Si': On the Care of the Common Home; understanding this text as a spiritual, moral, practical, and institutional tool that adds to the existing response repertoires to the global socio-environmental crisis. The content of the encyclical is not particularly new, but rather reaffirms the diagnosis of socio-ecological crisis and the need for a fundamental change in the dominant way of organizing collective life in the contemporary world. However, it does introduce, in a novel way, a strongly critical tone in the discourse of the Church about the path of deleterious development currently prevalent in the world, and makes a clear and urgent call for a "paradigm shift”.

Laudato Si'has been published in a particular historical context; a moment in which the evidences of the global environmental crisis and its consequences in nature do 
not find the necessary echo in the political, economic and social changes promoted and introduced in multiple global, regional, national and local instances. Over the last 40-50 years, the diagnosis of a "socio-ecological crisis" - that is, a crisis unleashed through socio-cultural processes that interact with the environment (Adger, Barnett, Brown, Marshall, \& O'Brien, 2013; UNESCO \& ISSC, 2013)—has become an salient topic in the scientific field, in the government and business agenda, as well as in public opinion (Ekins \& Salmons, 2010; Ghai \& Vivian, 2014; Running, 2012; Vig \& Kraft , 2012). However, despite the awareness of the environmental crisis, most of the negative trends in ecological systems continue to deepen, accelerate, and often reinforce each other. ${ }^{4}$ Concern for climate change, which emerged as a focal point for environmental issues in the middle of the first decade of the century, ${ }^{5}$ was complemented and enriched by the emergence of other theoretically and metaphorically powerful concepts: 1) the "Anthropocene" as a new geological era marked by mankind as the main transforming agent of biochemical and physical systems on a planetary scale (Bonneuil \& Fressoz, 2016; Crutzen, 2002; Crutzen \& Stoermer, 2000; Hamilton, Gemenne, \& Bonneuil, 2015; Latour, 2017), that accounts for the scale and space-time scope of current environmental changes; 2) the "Great Acceleration", that accounts for the historical uniqueness and exponential trajectory of these transformations (McNeill, 2001; Steffen, Broadgate, Deutsch, Gaffney, \& Ludwig, 2015), or 3) the “planetary limits” (Rockström, Steffen, Noone, Persson, Chapin, Lambin, Lenton, Scheffer, Folke, Schellnhuber, Nykvist, Wit, et al., 2009; Rockström, Steffen, Noone, Persson, Chapin, Lambin, Lenton, Scheffer, Folke, Schellnhuber, Nykvist, de Wit, et al., 2009; Steffen, Richardson, et al., 2015),

${ }^{4}$ For an overview of the state of the global and local environment, see the "Global Environment Outlook 6" report ( http://web.unep.org/geo). Updated data on global climate changes can be found on the IPCC website (www.ipcc.ch); and on biodiversity in the "Global Biodiversity Outlook 4" 2014 report (www.cbd.int) and the "Living Planet Report", 2016 ( http://wwf.panda.org).

${ }^{5}$ International attention turned to climate change, especially from 2006-2007, driven by the almost simultaneous appearance of the bestseller 'An inconvenient truth' by Al Gore, the Nobel Prize of the Intergovernmental Group of Experts on Climate Change (IPCC), which ratified the anthropic origin of global warming, and the Stern Report, which demonstrated the economic rationality of taking immediate and radical measures to change climate change. 
that set up progressive ranges of disruption of biogeochemical systems, in terms of their ability to sustain life (including human life). The impacts of these changes are immediately visible, and affect individuals and (human and non-human) communities throughout the world; ${ }^{6}$ and the projections of Business as Usual scenarios have provoked warnings about the ever-increasing probability of a global ecological collapse in the near future (Beck, 2015; Oreskes \& Conway, 2014; Servigne \& Stevens, 2015).

At the same time, however, more cars continue to be built each year, greenhouse gas emissions continue to increase at alarming rates, and economic growth, with the corresponding increase in the ecological footprint, remains the main concern of all governments. In their individual or collective practices, social actors reproduce (and identify with) an "imperial way of life" (Brand \& Wissen, 2013, 2017): that is to say, modes of life structurally dependent, for their own reproduction, of the externalization of costs of production and consumption to other regions of the world and future generations. ${ }^{7}$ It is, therefore, an inherently non-generalizable way of life, which, however, increasingly consolidates a model that defines the aspirational trajectories of people, penetrating "cultural imaginary and subjectivities strongly rooted in the daily practices of the majority in the countries of the North, but also and increasingly of the upper and middle classes in the emerging countries of the South " (Brand \& Wissen, 2013, pp. 446-447).

Global and local environmental policies seem to be caught in the same dilemma: they are intended, on the one hand, to manage the crisis and, on the other hand, to simultaneously guarantee the continuity of the capitalist consumption society and the universalization of the imperial mode of life. This gives rise to a particular form of response marked by the maintenance of the status quo or its gradual and partial reform. As much is clear in the various attempts to insert ecological concerns into current economic rationality. Since the 1980s, numerous studies have shown this

\footnotetext{
"For global data, see the "Atlas EJOLT" ( https://ejatlas.org/ ) (Temper, Demaria, Scheidel, Bene, \& Martinez-Alier, 2018).

7 For a more detailed elaboration of the concept of imperial lifestyles, see Lang and Brand's contributions to Beiling and Valhurst. "Desarrollo Non Sancto. La religión como actor emergente en el debate global sobre el futuro del planeta." Siglo XXI. 2019.
} 
tendency to respond to criticisms and alerts with neoclassical technical and economic tools (i.a. Brulle, 2010; Dobson, 2007; Dryzek, 2005; Hopwood, Mellor, \& O'Brien, 2005; Morin, Orsini, \& Jegen, 2015). This repertoire of responses that do not question the institutional and socio-cultural matrices of consumer capitalist societies and propose incremental adjustments to address environmental problems, can be subsumed under the conceptual label of an "ecological modernization" (Hajer, 1997; Mol, Sonnenfeld, \& Spaargaren, 2009). However, after 50 years of debates on the imperative of socio-ecological sustainability, multilevel governance for sustainability has not allowed the generation of the necessary changes and, supported by the general framework of ecological modernization, seems doomed to "sustain as long as possible what is known to be unsustainable" (Blühdorn, 2007). Paradoxically, reality has become utopian: the currently existing society model is unsustainable in geo-biophysical terms, to the point of receiving the name of "doomsday model" or "suicide model” (Beck, 2015; Oreskes \& Conway, 2014; Servigne \& Stevens, 2015).

The deconstruction of this unsustainable and potentially suicidal model of social organization is thus a fundamental and urgent task. Such deconstruction begins with the ideology that guides the evolutionary course of contemporary societies. From mid-twentieth century onwards, global socio-economic paths have converged around a particular normative idea: "development". In this sense, "development" can be understood as a historically contingent discourse, which, based on an economic vision of the world and a statistical toolbox managed by experts, defined a hierarchy of the world in supposedly objective terms, around indicators such as the growth of production and per capita income, schooling, life expectancy of individuals, or the existence of certain property regimes and certain political and commercial institutions. Since the 1970s, there has been a dichotomization of development discourse, between a current that saw development as economic growth and another that understood development as social policy. Institutions such as the World Bank, the International Monetary Fund (IMF) and the World Trade Organization (WTO) canonized the idea of development as growth, while UNDP (United Nations Development Program) and UNEP (United Nations Environment Program), as well as most of the international NGOs of the so-called "development cooperation" 
endorsed the idea of development as social policy (Sachs, 2017) . Thus, the term "development" became an ambiguous and multipurpose label that could be used, for example, to refer both to the drilling of a water wells for the need of a community or to the drilling (or more recently fracking) for oil extraction. The idea of "development" is, therefore, the floating signifier around which the global sociopolitical imaginary was built and consolidated. Various adjectives were added to de development, expressing the necessary historically variable nuances of the same worldview: endogenous development, ethnodevelopment, ecodevelopment, human scale development, human development, and sustainable development were attached to development as its own name. However, the Eurocentric, economy first and naturalist foundation of "development" was rarely questioned as the root of the global socio-ecological predicament.

Laudato Si' sees the light in June 2015, a key year for global debates and negotiations on Society and Environment. In September 2015, the United Nations formalized an international program aimed at promoting sustainable development until 2030: the Sustainable Development Goals (SDGs) —also known as the 2030 Agenda-as a continuation of the so-called "Millenium Development Goals". In addition, in December of the same year, the most important global summit on climate change in the post-Kyoto phase took place in Paris: the Conference of Parties 21 (COP21) of the United Nations Framework Convention on Climate Change. With the publication of Laudato Si' in anticipation to these events, for the first time in the history of Catholic social doctrine, a papal encyclical deals with systematic and extensive "environmental issues", linking it to the issue of global development, recognizing clear links between the prevalent today's lifestyles and the global environmental crisis. Thus, while the UN Sustainable Development Goals have their roots deeply installed in the prevalent imaginary of development, Laudato Si' opens a historic opportunity for a critical reflection on development discourse, its leading role in the dominant political and economic order in the world, and its global consequences.

It is a social and ecological encyclical penetrated by both the issue of social justice and the issue of the pathologies of contemporary society. Indeed, Laudato Si' position 
very critically towards the current capitalist industrial society model and its modes of production and consumption. In addition, it takes sides with those most affected by an economic system predatory of people and nature. In this sense, it has surprised, both inside and outside the Church, crossing religious and ideological boundaries; and has put urgent topics on the table of political and social debate for humanity and his home, the Earth. It has raised questions such as: how to overcome world poverty in a hyper-economized world and in accelerated ecological degradation? How to reach ways of socio-ecologically sustainable life? How to limit climate change caused by human beings? How to guarantee a dignified life in the rural environment and in expanding cities?

The British newspaper The Guardian speaks of the "most surprising and, perhaps, ambitious document of a Pope in the last hundred years." 8 Scientific journals Nature 9 and Science ${ }^{10}$ have inserted the encyclical in their respective editorials: "This is unprecedented in the western history of the dialogue between religion and science". Edgar Morin, French sociologist and emeritus director of research of the French National Center for Scientific Research, who declares himself an atheist, speaks of a document "providential" for its extraordinary character "in a time of desert of thought." ${ }^{11}$ Leonardo Boff, the Brazilian liberation theologian, refers to Laudato Si' as the "Magna Carta of an integral ecology"; ${ }^{12}$ Canadian activist Naomi Klein, who defines herself as a secular and feminist Jew, praises the Pope's courage to "point to

\footnotetext{
8 www.theguardian.com/commentisfree/2015/jun/18/guardian-view-onlaudato-si-pope-franciscultural-revolution

9 Nature 522, 391 (2015)

10 Mc Nutt, M., Science 349, 6243 (2015)

1 Morin, Edgar: "L'encyclique Laudato Si 'est peut-être l'acte 1 d'un appel pour une nouvelle civilization"; la croix, 06/12/2015, www.la-croix.com/Religion/Actualite/Edgar-Morin-Lencyclique-Laudato-Si-est-peut-etre-l-acte-1-d-unappel-pour -une-nouvelle-civilization-2015-0621-1326175

12 Boff, Leonardo, 06/18/2015, www.leonardoboff.wordpress.com/2015/06/18/the-magna-cartaof-integral-ecology-cry-ofthe-earth-cry-of-the -poor / [Spanish version: https://leonardoboff.wordpress.com/2015/06/18/la-carta-magna-de-laecologia-integral-gritode-la-tierra-grito-de-los-poor / ] 
the root causes of the climate crisis, and decisively condemn not only inaction, but also half measures and false solutions like carbon markets and other proposals that lend themselves to speculation, as well as consumerism." ${ }^{13}$ The then US president Barak Obama expressed his hope that, in the prelude to the Paris Climate Summit, "all world leaders and all the children of God reflect on the call of Pope Francis to unite to take care of our common home." ${ }^{14}$ US environmental activist Bill McKibben defines Laudato Si' as "one of the most influential documents of recent times." ${ }^{15}$ The former executive director of the United Nations environment program, Klaus Töpfer, calls the encyclical "therapeutic guide for our society." 16

However, not everything is praise for the papal document. There are those who, on the other hand, raise their voices in outrage: the Frankfurter Allgemeine Zeitung entitled "How the Pope is wrong", a counterattack to a document he contends is "full of criticisms of civilization and anti-liberal distortions"; ${ }^{17}$ while the Heartland Institute, a conservative American think tank, replies to Pope Francis stating "global warming is not a crisis". In the same vein, coal industry lobbyists responded with the antithesis of the encyclical, arguing the necessary fossil fuel promotion to help the poor. ${ }^{18}$ In his presidential campaign, Jeb Bush echoed the vision of the entire dome of the US Republican Party, the fossil fuel industry and climate change deniers to try to discredit the papal message, even before its launch, underlining that "I think religion ought to be about making us better as people and less about things that end up getting in the political realm." ${ }^{19}$ Laudato Si' thus undresses the deeply normative character of contemporary debates about the relationship between human society and non-human nature, normativity that is usually hidden behind a pseudo-objective technical and economic layer. Such reactions show that, globally, Francisco's

\footnotetext{
${ }^{13} \mathrm{https} / / /$ www.youtube.com/watch?v=7jUkwGziumc

${ }^{14}$ Catholic Herald: "Obama calls for world leaders to heed Pope Francis's message», www.catholicherald.co.uk/news/2015/o6/19/obama-calls-for-world-leaders-to-heed-popefranciss-message/ 
Unholy Development | 22

encyclical has been received as, at the very least, a strong provocation to the status quo.

But Laudato Si' does not constitute an isolated expression. With this encyclical, Pope Francis opens the way to a new religious narrative of "integral ecology", which also informs, for example, the Joint Declaration of Religions at COP21 in Paris. This narrative is inscribed in a continuity with the traditional orientation of Christianity towards sobriety, justice and the protection of the marginalized and the most vulnerable; but it introduces in a rather novel way three central dimensions: the care of the environment (the "common home"), the links between environmental and social justice, and the inexorable criticism of economicism and the blind technooptimism as determining parameters of the current trajectory of the global development. These voices from the religious sphere come to join a growing choir that advocates a fundamental transformation of social, political and economic arrangements established by industrial and consumer societies, and that have become particularly visible since the 2000s: ${ }^{20}$ Arturo Escobar (2011) has called them "transformation" or "transition discourses". In contrast to the approaches that advocate the reproduction of the status quo, transition discourses seek to promote a change in subjective and objectives conditions that maintain unsustainability.

The originality and uniqueness of Laudato $\mathrm{Si}^{\prime}$, as a socio-political event, opens a historical window of opportunity to install the debate on development and environment in a regional and global public sphere, on the one hand, and, on the other, for the formation of new discursive alliances and operational, including the religious world. At the same time, this opening to and from the world of institutionalized religion involves several risks. The first type of risk is that of cooptation, dilution or trivialization of the "inconvenient truths" of the encyclical. In particular, the international consensus around the United Nations Sustainable Development Goals (SDGs) threatens to colonize the discursive space around issues of development and ecology, making invisible or diluting the disruptive message of

\footnotetext{
${ }^{20}$ As an example, we can mention the discourses of Degrowth, Convivialism, Buen vivir, Food Sovereignty, Post-extractivism, Eco-feminism, Rights of nature, or the Global Movement for Environmental Justice.
} 
Pope Francis regarding the "development consensus". The second type of risk is the potential perversion of emancipatory religious impulses in the form of "post-truth" demagogic coalitions between reemergent right-wing political extremism and rapidly expanding right-wing religious formations, both in the north and in the south. The first type of risk would lead to the reduction of the interpellation made by Pope Francis to a mere "environmental awareness", while the second type would imply strengthening climate denialism, as well as various social forms of symbolic and physical violence.

Thus, in a context of technocratic socio-environmental governance, on the one hand, and demagogy on the other, it seems especially urgent and relevant to re-politicize the cultural debate about the necessary "civilizational transition", undressing the biases of the currently hegemonic representations of the world and offering representations and possibilities of alternative future.

\section{Bibliography}

Adger, WN, Barnett, J., Brown, K., Marshall, N., \& O'Brien, K. (2013). 'Cultural dimensions of climate change impacts and adaptation'. Nature Climate Change, 3 (2), 112-117. https://doi.org/10.1038/nclimate1666

Beck, U. (2015). Ecological Politics in an Age of Risk. UK: Polity Press.

Blühdorn, I. (2007). Sustaining the unsustainable: Symbolic politics and the politics of simulation". Environmental Politics, $16 \quad$ (2), 251-275. https://doi.org/10.1080/09644010701211759

Bonneuil, C., \& Fressoz, J. (2016). L'Événement Anthropocène. La Terre, l'histoire et nous (édition revue et augmentée). Points

Brand, U., \& Wissen, M. (2013). 'Socioecological crisis and imperial way of life. Crisis and continuity of society-Nature relations in capitalism'. In Permanent Working Group on Alternatives to Development (Ed.), Alternatives to 21st Century Capitalism (pp. 445-470). Quito - Ecuador: Rosa Luxemburg Foundation - Abya Yala. 
Unholy Development | 24

Brand, U., \& Wissen, M. (2017). Imperiale Lebensweise: zur Ausbeutung von Mensch und Natur im globalen Kapitalismus. Oekom Verlag.

Brulle, R. (2010). 'Politics and the environment'. In in Leicht K. \& Jenkins J. (Eds.), The handbook of politics: State and Civil Society in Global. (Perspective Springer Publishers, pp. 385-406). New York

Catton, WR, \& Dunlap, RE (1978). 'Environmental Sociology: A New Paradigm'. The American Sociologist, 13 (1), 41-49.

Catton, WR, \& Dunlap, RE (1980). 'A New Ecological Paradigm for PostExuberant Sociology'. American Behavioral Scientist, 24 (1), 15-47. https://doi.org/10.1177/000276428002400103

Crutzen, PJ (2002). 'Geology of mankind'. Nature, 415 (6867), 23-23. https://doi.org/10.1038/415023a

Crutzen, PJ, \& Stoermer, E. (2000). The "Anthropocene." Global Change Newsletter, (41), 17-18.

Dobson, A. (2007). Green Political Thought (4th ed.). Routledge

Dryzek, JS (2005). The politics of the earth: environmental discourses. Oxford University Press.

Dunlap, RE, \& Catton, WR (1979). Environmental Sociology Annual Review of Sociology, 5, 243-273.

Ekins, P., \& Salmons, R. (2010). 'Making reform happen in environmental policy'. In Making Reform Happen (pp. 129-157). Organization for Economic Cooperation and Development. Retrieved from http://www.oecdilibrary.org/content/chapter/9789264086296-6-en

Escobar, A. (2011). 'Sustainability: Design for the pluriverse'. Development, 54 (2), 137-140. https://doi.org/10.1057/dev.2011.28

Ghai, D., \& Vivian, JM (2014). Grassroots Environmental Action: People's Participation in Sustainable Development. Routledge 
Gottlieb, RS (2006a). A Greener Faith: Religious Environmentalism and Our Planet's Future. OUP USA

Gottlieb, RS (2006b). The Oxford Handbook of Religion and Ecology. Oxford University Press, USA.

Hajer, MA (1997). The Politics of Environmental Discourse: Ecological Modernization and the Policy Process. Oxford University Press.

Hamilton, C., Gemenne, F., \& Bonneuil, C. (2015). The Anthropocene and the Global Environmental Crisis: Rethinking modernity in a new epoch. Routledge

Hopwood, B., Mellor, M., \& O'Brien, G. (2005). 'Sustainable development: mapping different approaches'. Sustainable Development, 13 (1), 38-52. https://doi.org/10.1002/sd.244

Hulme, M. (2016). Climate change: Varieties of religious engagement". In WJ Jenkins, ME Tucker, \& J. Grim (Eds.), Routledge Handbook of Religion and Ecology (pp. 237-246). Routledge

Jenkins, WJ, Tucker, ME, \& Grim, J. (Eds.). (2016). Routledge Handbook of Religion and Ecology. Routledge

Latour, B. (2017). Facing Gaia: Eight Lectures on the New Climatic Regime. Wiley Lélé, SM (1991). 'Sustainable development: A critical review'. World Development, 19 (6), 607-621.

Lélé, SM (2013). 'Rethinking sustainable development'. Current History, 112 (757), 311-316.

McNeill, JR (2001). Something New Under the Sun: An Environmental History of the Twentieth-Century World (The Global Century Series). WW Norton \& Company.

Mol, APJ, Sonnenfeld, DA, \& Spaargaren, G. (2009). The Ecological Modernisation Reader: Environmental Reform in Theory and Practice. Routledge 
Unholy Development | 26

Morin, J.-F., Orsini, A., \& Jegen, M. (2015). Politique internationale de l'environnement. Sciences Po. Presses

Oreskes, N., \& Conway, EM (2014). The Collapse of Western Civilization: A View from the Future. Columbia University Press.

Paulson, S. (2017). Degrowth: Culture, Power and Change. Journal of Political Ecology 24 (2017): 425-48.

Polanyi, K. (1944). The Great Transformation, Boston: Beacon Press.

Somers, M. R., and Block, F. (2014). The Return of Karl Polanyi. Dissent. A Quarterly of Politics and Culture (blog), http://www.dissentmagazine.org/article/the-return-of-karl-polanyi.

Perkiss, S., \& Tweedie, D. (2017). 'Social Accounting into Action: Religion as "Moral Source." Social and Environmental Accountability Journal, 37 (3), 174-189. https://doi.org/10.1080/0969160X.2017.1312473

Rockström, J., Steffen, W., Noone, K., Persson, Å., Chapin, FS, Lambin, EF, ... Foley, JA (2009). 'A safe operating space for humanity'. Nature, 461 (7263), $472-$ 475. https://doi.org/10.1038/461472a

Rockström, J., Steffen, W., Noone, K., Persson, Å., Chapin, FS, Lambin, E., ... Liverman, D. (et al). (2009). 'Planetary boundaries: exploring the safe operating space for humanity'. Ecology and Society, 14 (2), article 32.

Running, K. (2012). 'Examining environmental concern in developed, transitioning and developing countries: A cross-country test of the objective problems and the subjective values explanations'. World Values Research, 5 (1), 1-25.

Sachs, W. (2017). 'The Sustainable Development Goals and Laudato si ': varieties of Post-Development?' Third World Quarterly, 38 (12), 2573-2587. https://doi.org/10.1080/01436597.2017.1350822

Servigne, P., \& Stevens, R. (2015). Comment tout peut s'effondrer. Petit manuel de collapsologie à l'usage des générations present. Le Seuil 
Sneddon, C., Howarth, RB, \& Norgaard, RB (2006). 'Sustainable development in a post-Brundtland world'. Ecological Economics, $57 \quad$ (2), 253-268. https://doi.org/10.1016/j.ecolecon.2005.04.013

Steffen, W., Broadgate, W., Deutsch, L., Gaffney, O., \& Ludwig, C. (2015). 'The trajectory of the Anthropocene: The Great Acceleration'. The Anthropocene Review, 2 (1), 81-98. https://doi.org/10.1177/2053019614564785

Steffen, W., Richardson, K., Rockström, J., Cornell, SE, Fetzer, I., Bennett, EM, ... Sörlin, S. (2015). 'Planetary boundaries: Guiding human development on a changing planet'. Science, 1259855. https://doi.org/10.1126/science.1259855

Temper, L., Demaria, F., Scheidel, A., Bene, DD, \& Martinez-Alier, J. (2018). 'The Global Environmental Justice Atlas (EJAtlas): ecological distribution conflicts as forces for sustainability'. Sustainability Science, 13 (3), 573-584. https://doi.org/10.1007/s11625-018-0563-4

Tucker, ME (2008).' World Religions, the Earth Charter, and Sustainability'. Worldviews: Global Religions, Culture, and Ecology, 12 (2), 115-128. https://doi.org/10.1163/156853508X359930

Tucker, ME (2015). 'World Religions, Ethics, and the Earth Charter for a Sustainable Future'. In Earth Stewardship (pp. 395-405). Springer, Cham. https://doi.org/10.1007/978-3-319-12133-8_26

UNESCO, \& ISSC. (2013). World Social Science Report 2013: Changing Global Environments. UNESCO

Van Opstal, M., \& Hugé, J. (2013). 'Knowledge for sustainable development: a worldviews perspective'. Environment, Development and Sustainability, 15 (3), 687-709. https://doi.org/10.1007/s10668-012-9401-5

Vanhulst, J. (2015). Les chemins sinueux du développement durable. Une Analyze of Latin American Academic Discourses (Thèse de doctorat). Université Libre de Bruxelles \& Alberto Hurtado University, Santiago, Chile. 
Vanhulst, J., \& Beling, AE (2013). 'Good living and durable développement: rupture ou continuité ?' Ecologie \& Politique, 1/2013 (46).凹

Vanhulst, J., \& Zaccai, E. (2016). 'Sustainability in latin America: An analysis of the academic discursive field.' Environmental Development, 20, 68-82. https://doi.org/10.1016/j.envdev.2016.10.005

Vig, NJ, \& Kraft, ME (2012). Environmental Policy: New Directions for the Twenty-First Century. CQ Press

Villalba, B. (Ed.). (2009). Appropriations du développement durable: émergences, diffusions, traductions. Presses Univ. Septentrion. 